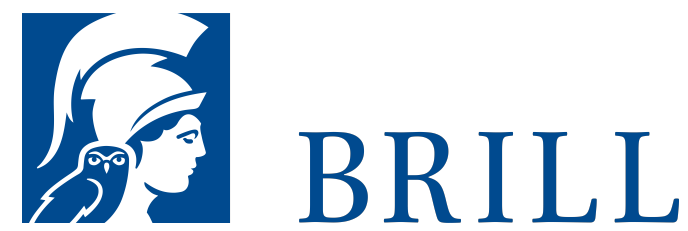

\title{
National Identities and the Right to Self- Determination of Peoples
}

"Civic -Nationalism -Plus" in Israel and Other Multinational States

Author: Hilly Moodrick-Even Khen

In National Identities and the Right to Self-Determination of Peoples, Hilly Moodrick-Even Khen revisits the legal right to self-determination of peoples and suggests an integrative model for securing the cohesion of the various nationalities within multinational states. The model, set on both legal and political science theories, departs from civic nationalism but calls to strengthen it with more immediate and emotional means, such as shared national symbols and multicultural education. Moodrick-Even Khen explores the political history of Canada, Belgium, and Spain and touches upon other divided societies such as South Africa, Northern Ireland and Cyprus. Drawing upon these cases, she suggests a future model for a cohesive society in Israel, which is currently nationally divided between Arabs and Jews.

\section{Readership}

Academic libraries, specialists, students of international law, political science and education (graduate and post-graduate), think tanks in these fields, educated laymen and public activists and politicians.

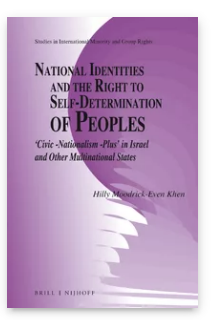

Pages: $\mathrm{x}, 214 \mathrm{pp}$.

Language:

English

Subjects:

International

Law: General

Interest,

International

Law,

Comparative

Law,

International

Law, Human

Rights, Human

Rights and

Humanitarian

Law, Minority \&

Group Rights,

Human Rights

and

Humanitarian

Law, Public

International

Law,

International

Law

Publisher: Brill |

Nijhoff

Series:

Studies in

International

Minority and

Group Rights,

Volume: 12 
Hilly Moodrick-Even Khen, LL.D (2007), is a senior lecturer in ISBN: 978-90The Academic Center of Law and Science. She has published O4-29433-2 articles in various branches of international law and a book on terrorism and international humanitarian law (Hebrew List price University, 2010).

For more information see brill.com

Order information: Order online at brill.com +44330 333 o049 | customerservices@brill.com Submission information: brill.com/authors

USD ÂA $\$ 162.00$

Hardback

Publication date: 16 Jun 2016

ISBN: 978-9004-29432-5 List price USD Â \$162.00 Titles published by Brill | Fink, Brill | mentis or Brill | Schöningh: +49(o)71 5413279216 | brill@brocom.de 